\title{
Large bowel fermentation in rats eating processed potatoes
}

\author{
BY J. C. MATHERS AND LINDSAY D. DAWSON \\ Department of Agricultural Biochemistry and Nutrition, University of Newcastle upon Tyne, \\ Newcastle upon Tyne NEI $7 R U$
}

(Received 8 October 1990 - Accepted 10 December 1990)

\begin{abstract}
Four diets were prepared in which cooked potatoes provided approximately 0.8 of the dry matter (DM) and all the polysaccharides. The potatoes were either boiled conventionally (unprocessed) or prepared by rehydrating a commercial 'instant' potato product with boiling water. The diets were fed to rats (six per diet) immediately after preparation or after storage at $4^{\circ}$ for $48 \mathrm{~h}$ and observations made on site and extent of digestion and large bowel (LB) fermentation. All diets were equally well digested (overall means 0.95 and 0.96 for $D M$ and organic matter $(O M)$ respectively) with a significant proportion of this digestion occurring in the LB. More OM flowed to the LB with the 'instant' ( 0.18 of intake) than with the unprocessed potato diets (0.13 of intake) and was associated with markedly different fermentation patterns. When compared with rats fed on the unprocessed potato diets, those given 'instant' potatoes had smaller caecums with much shorter transit times, lower caecal pH, higher total volatile fatty acid (VFA) concentrations and a greater molar proportion of butyrate in these VFA. Storage of the diets for $48 \mathrm{~h}$ at $4^{\circ}$ had relatively smaller effects on these variables. Possible mechanisms for the observed effects and implications for tissue metabolism and health are discussed. In addition, a simple and apparently novel method for quantifying coprophagy is proposed.
\end{abstract}

Large bowel fermentation: Potato processing: Starch digestion

The potato is an international staple crop which has now spread to at least three-quarters of the world's countries from its origins in South America (Woolfe, 1987). The tuber is rich in carbohydrates, the principal of which is starch present as granules consisting of amylopectin and amylose in the ratio of approximately $3: 1$. In their native state, these starch granules show considerable resistance to pancreatic $\alpha$-amylase (EC 3.2.1 1 1; Englyst \& Cummings, 1987a), escape small intestinal digestion and stimulate large bowel (LB) fermentation (Demigné \& Rémésy, 1982). For this reason, potatoes are normally processed by some form of heating before consumption by man. The cooked potatoes may be eaten hot or sometime later when cold.

The present experiment was designed to investigate, in the rat, the effects on site and extent of digestion and on LB fermentation of feeding diets in which potatoes provided most $(0 \cdot 8)$ of the dry matter $(\mathrm{DM})$ and all the polysaccharides. Studies using breath hydrogen as an index of LB fermentation (Anderson et al. 1981; Flourié et al. 1988) and direct measurements of flow through the terminal ileum using ileostomate volunteers (Chapman et al. 1985; Englyst \& Cummings, 1985, 1986, 1987a) and intact healthy volunteers in whom a multi-lumen tube was positioned close to the ileo-caecal junction (Stephen et al. 1983; Flourié et al. 1988) have all indicated that a significant but variable proportion of the starch in various foods escapes small intestinal digestion and flows to the LB where it is presumed to be fermented. As yet, there is relatively little information on the effects of starch in the LB. Some of this starch escaping small intestinal digestion may be physically inaccessible to pancreatic $\alpha$-amylase whilst some will have been rendered resistant due to retrogradation (resistant starch; RS) which occurs when a cooked, starch- 
Table 1. Composition of mineral and vitamin premix

\begin{tabular}{|c|c|c|c|}
\hline Mineral & $\begin{array}{l}\text { Per kg } \\
\text { premix }\end{array}$ & Vitamin & $\begin{array}{l}\text { Per kg } \\
\text { premix }\end{array}$ \\
\hline $\mathrm{CaHPO}_{4}$ & $340 \mathrm{~g}$ & Rovimix $\mathrm{AD}_{3} 500 / 100^{*}$ & $200 \mathrm{mg}$ \\
\hline $\mathrm{NaCl}$ & $26 \mathrm{~g}$ & Rovimix $\mathrm{E}_{50}$ adsorbate* & $1.2 \mathrm{~g}$ \\
\hline $\mathrm{FeSO}_{4} \cdot 7 \mathrm{H}_{2} \mathrm{O}$ & $2.4 \mathrm{~g}$ & Menadione & $10 \mathrm{mg}$ \\
\hline $\mathrm{ZnSO}_{4} \cdot 7 \mathrm{H}_{2} \mathrm{O}$ & $1 \cdot 1 \mathrm{~g}$ & Choline chloride & $27 \mathrm{~g}$ \\
\hline $\mathrm{MnSO}_{4} \cdot 4 \mathrm{H}_{2} \mathrm{O}$ & $4.0 \mathrm{~g}$ & Calcium pantothenate & $100 \mathrm{~g}$ \\
\hline \multirow[t]{2}{*}{$\mathrm{KIO}_{3}$} & $5.0 \mathrm{mg}$ & Folic acid & $15 \mathrm{mg}$ \\
\hline & & Riboflavin & $40 \mathrm{mg}$ \\
\hline \multirow[t]{2}{*}{$\mathrm{Cr}_{2} \mathrm{O}_{3} \uparrow$} & $40 \mathrm{~g}$ & Thiamin & $20 \mathrm{mg}$ \\
\hline & & Vitamin $\mathbf{B}_{12}$ & $1 \mathrm{mg}$ \\
\hline Sucrose & $557.9 \mathrm{~g}$ & & \\
\hline
\end{tabular}

rich product is allowed to cool (Englyst \& Cummings, 1987b). In the present study we compared conventionally boiled potatoes with a commercial 'instant' product and fed each type of potato to rats when freshly prepared or after storage at $4^{\circ}$ for $48 \mathrm{~h}$. We anticipated that such storage would increase the amount of RS present which might influence substrate flow to the LB with subsequent effects on fermentation in that organ.

\section{MATERIALS AND METHODS}

Diets and feeding

Four diets were used in which potatoes provided approximately 0.8 of DM intake. For diets 1 and 2, unprocessed potatoes (var. Home Guard; A. S. McLaren \& Son, Keillow, Methuen, Perthshire) were peeled, boiled for $20 \mathrm{~min}$ in tap water (without added salt), drained thoroughly, mashed immediately and $1 \mathrm{~kg}$ freshly mashed potato was mixed with $50 \mathrm{~g}$ supplement containing $(\mathrm{g} / \mathrm{kg}$ ) casein 485 , maize oil 250 , mineral and vitamin premix (Table 1) 250 and L-methionine 15 . This mixture was fed either immediately (diet 1) or after storage at $4^{\circ}$ for $48 \mathrm{~h}$ (diet 2). Diets 3 and 4 were prepared by mixing instant mashed potato (Yeoman brand; Dornay Foods, PO Box 15, Kings Lynn, Norfolk PE30 4JE) and supplement in the ratio $4: 1(\mathrm{w} / \mathrm{w})$. When required, $225 \mathrm{~g}$ of this mixture was stirred into $900 \mathrm{ml}$ boiling tap water and fed either immediately (diet 3) or after storage at $4^{\circ}$ for $48 \mathrm{~h}$ (diet 4). Thus, all four diets contained approximately $0.2 \mathrm{DM}$ as fed and each animal was offered $60 \mathrm{~g}$ moist diet daily at 10.00 hours. Food residues were removed at 14.00 hours. Animals had ad lib. access to water.

\section{Animals and housing}

Twenty-four male Wistar rats, initial weight 150 (SD 5.4) g, were divided into four dietary groups each of six animals and housed in individual metabolism cages (Thompson, 1970).

\section{Measurements}

After $10 \mathrm{~d}$ adaptation, food intake and faecal and urinary output were measured for $7 \mathrm{~d}$. Each day, samples of the diets offered were dried at $100^{\circ}$ as were all food residues to obtain a measure of DM intake. Faeces were collected daily, composited for each animal and stored at $-20^{\circ}$ before being freeze-dried and ground for analysis. Urine was collected into flasks containing $2 \mathrm{ml} 6 \mathrm{M}$-hydrochloric acid.

Between 14.00 and 17.00 hours, rats were anaesthetized with diethyl ether, a mid-line 
laparotomy was performed to expose the abdominal organs and the stomach, small intestine, caecum, colon and liver were dissected out. The terminal one-sixth by length of the small intestine was excised and the contents collected by flushing through with $5 \mathrm{ml}$ saline $(0.9 \mathrm{~g}$ sodium chloride $/ 1)$. The caecum was weighed and the $\mathrm{pH}$ of its contents measured using a micro-electrode. Duplicate weighed samples (approximately $1 \mathrm{~g}$ ) of caecal contents were mixed $2: 1(\mathrm{w} / \mathrm{v})$ with deproteinizing solution (metaphosphoric acid solution $(200 \mathrm{~g} / \mathrm{l})$ containing $50 \mathrm{~mm}-3$-methyl valeric acid) in preparation for volatile fatty acid (VFA) determinations. Further samples of caecal contents were transferred into preweighed tubes for determination of DM and chromic oxide contents. The caecal tissue was washed, blotted dry and weighed. The stomach and colon were treated as for the caecum except that pH and VFA were not measured. The liver was rinsed in saline, blotted dry and weighed.

\section{Analysis}

VFA in caecal contents were measured by gas-liquid chromatography using a $2 \mathrm{~mm}$ i.d. column packed with $10 \%$ SP-1200/1 \% phosphoric acid on $80 / 100$ Chromosorb (Supelco Inc., Bellefonte, Pennsylvania 16823, USA) in a Series 204 gas-liquid chromatograph (Pye Unicam, Cambridge). Samples of diet, faeces and of stomach, small intestinal, caecal and colonic contents were freeze-dried and ground before analysis. Subsequently for determination of $\mathrm{DM}$, organic matter $(\mathrm{OM})$ and $\mathrm{Cr}_{2} \mathrm{O}_{3}$ contents, portions $(60-100 \mathrm{mg})$ were weighed into predried and preweighed graduated Pyrex tubes, dried at $100^{\circ}$ for at least $5 \mathrm{~h}$, re-weighed, ashed at $450^{\circ}$ for $16 \mathrm{~h}$ and re-weighed. Two or three anti-bumping granules were added and the residue was digested using $1.2 \mathrm{ml}$ acid mixture $\left(300 \mathrm{ml} \mathrm{MnSO}{ }_{4} .4 \mathrm{H}_{2} \mathrm{O}\right.$ solution $(100 \mathrm{~g} / \mathrm{l})$ diluted to 1 litre with orthophosphoric acid) and $1.6 \mathrm{ml}$ potassium bromate solution $\left(45 \mathrm{~g} \mathrm{KBrO}_{3} / 1\right)$ and made up to $10 \mathrm{ml}$ with distilled water. To portions of the digest, $1 \mathrm{ml}$ calcium chloride solution $\left(5.47 \mathrm{~g} \mathrm{CaCl}_{2}, 6 \mathrm{H}_{2} \mathrm{O} / 1\right)$ and $0.1 \mathrm{ml}$ sodium silicate solution $\left(7.55 \mathrm{~g} \mathrm{Na}_{2} \mathrm{SiO}_{3} .5 \mathrm{H}_{2} \mathrm{O} / 1\right)$ were added and, after appropriate dilution, the chromium concentration was measured by atomic absorption spectrophotometry (SP9; Pye Unicam, Cambridge, UK).

For total starch determination, $500 \mathrm{mg}$ portions of diet were treated with $1 \mathrm{ml}$ dimethyl sulphoxide for $5 \mathrm{~min}$ at room temperature, $10 \mathrm{ml} 0 \cdot 1 \mathrm{M}$-sodium acetate buffer $(\mathrm{pH} \mathrm{5 \cdot 2)}$ was added, the tubes were capped and heated in a boiling water-bath for $1 \mathrm{~h}$. The tube contents were allowed to cool to approximately $50^{\circ}, 0.2 \mathrm{ml}$ amyloglucosidase (EC 3.2.1.3; Sigma Chemical Co. Ltd) was added and the samples incubated at $55^{\circ}$ overnight. The resulting glucose was measured by a glucose dehydrogenase (EC 1.1.3.4) method (MA Kit 100; Roche) using a Cobas Mira clinical analyser (Roche). Readily digested starch was measured by incubating $500 \mathrm{mg}$ diet suspended in $10 \mathrm{ml}$ saline with $100 \mu \mathrm{l}$ pancreatin solution ( $100 \mathrm{mg}$ pancreatin $(4 \times \mathrm{NF}$ Grade; Sigma $) / \mathrm{ml}$ saline) with constant stirring at $37^{\circ}$ for $2 \mathrm{~h}$. Undigested starch was precipitated with aqueous ethanol $(850 \mathrm{ml} / \mathrm{l})$, washed with a further $40 \mathrm{ml}$ aqueous ethanol $(850 \mathrm{ml} / \mathrm{l})$, dried with acetone and assayed as described previously for total starch.

\section{Calculations}

Apparent digestibility and flow-rate from the terminal ileum were calculated by markerratio methods. Caecal and colonic transit times (TT) were calculated as:

$$
\frac{\text { mass of } \mathrm{Cr}_{2} \mathrm{O}_{3} \text { in organ }(\mathrm{mg})}{\text { daily } \mathrm{Cr}_{2} \mathrm{O}_{3} \text { intake }(\mathrm{mg} / \mathrm{d})} \text {, }
$$

as described by Faichney (1975) and Goodlad \& Mathers (1987).

An estimate of the extent of coprophagy was obtained from knowledge of the concentration of $\mathrm{Cr}_{2} \mathrm{O}_{3}$ in the DM in the diet (D), in faeces $(F)$ and in stomach contents 
(S). Assuming that the sources of stomach DM were food and faeces, the proportion of stomach contents obtained directly from ingested food was:

$$
\frac{S-F}{D-F}
$$

DM and OM disappearances in the LB were calculated as ileal flow-rate minus faecal output.

Estimates of VFA absorption were obtained from knowledge of caecal VFA proportions and of $\mathrm{OM}$ disappearance in the LB on the assumption that anhydrous hexose was the substrate fermented, i.e. $\mathrm{C}_{6}=\mathrm{A} / 2+\mathrm{P} / 2+\mathrm{B}$, where $\mathrm{C}_{6}$ is mol hexose fermented and $\mathrm{A}, \mathrm{P}$ and $\mathrm{B}$ are mol acetate, propionate and butyrate absorbed (Demeyer \& Van Nevel, 1975).

\section{Statistical analysis}

Data were examined by one-way analysis of variance in which the $3 \mathrm{df}$ and accompanying sums of squares associated with between-diets differences were partitioned into single df orthogonal contrasts as follows: contrast 1, unprocessed potato $v$. 'instant' potato; contrast 2 , freshly-prepared diets $v$. stored diets; contrast 3 , (unprocessed potato $v$. 'instant' potato $) \times($ freshly-prepared diets $v$. stored diets $)$, i.e. the interaction between potato type and storage. In each case, the contrast mean square was compared with the between-animals within-diets mean square (which had $20 \mathrm{df}$ ) using an $F$ test.

The relationship between the molar proportion of butyrate in VFA in caecal contents and caecal transit time in Fig. 1 is indicated by an hyperbola fitted using the maximum likelihood program (Ross, 1980). This curve was chosen for descriptive reasons since it accounted for a considerably higher proportion $(0.60)$ of the variation in caecal butyrate than did the alternatives tested, i.e. exponential $(0 \cdot 30)$, power $(0 \cdot 40)$, logarithmic $(0 \cdot 43)$ and quadratic $(0 \cdot 46)$ curves.

\section{RESULTS}

\section{Food intake, growth and DM digestibility}

Rats on all diets lost weight during the first $5 \mathrm{~d}$ of the experiment whilst they became accustomed to eating these low-energy-density diets during the $4 \mathrm{~h}$ daily that food was available to them. One animal was replaced because of persistently low intakes. Thereafter, the animals regained the lost weight and during the final $7-9 \mathrm{~d}$ showed modest rates of weight gain which were not significantly different between diets (Table 2), but the relatively large between-animal within-diets variation should be noted. Significantly $(P<0.001)$ greater amounts of the 'instant'-potato diets compared with unprocessed-potato diets were eaten, as were diets stored for $48 \mathrm{~h}$ at $4^{\circ}$ before feeding compared with freshly-prepared diets; the latter effect was due mainly to the relatively low intake of the freshly-prepared, unprocessed-potato diet (diet 1). For all diets, faeces were scanty with wet, poorly-formed pellets which made total collection unreliable. Consequently, all estimates of digestibility were based on the marker-ratio method. DM apparent digestibility was very similar for all diets with an overall mean of 0.95 and a relatively low coefficient of variation of 0.07 . Rats eating the 'instant'-potato diets excreted slightly, but not significantly $(P>0.05)$, more urine than those eating the unprocessed-potato diets, perhaps because of the higher intakes and greater salt content of the former.

\section{Tissue weights}

At slaughter, the rat's stomachs appeared very full and contained approximately $25 \mathrm{~g}$ contents, equivalent to 0.13 of live weight. There were no significant effects of diet on masses of stomach or colon, but caecal mass was 1.5 times greater with unprocessed-potato diets when compared with 'instant'-potato diets (Table 3). This caecal hypertrophy was 


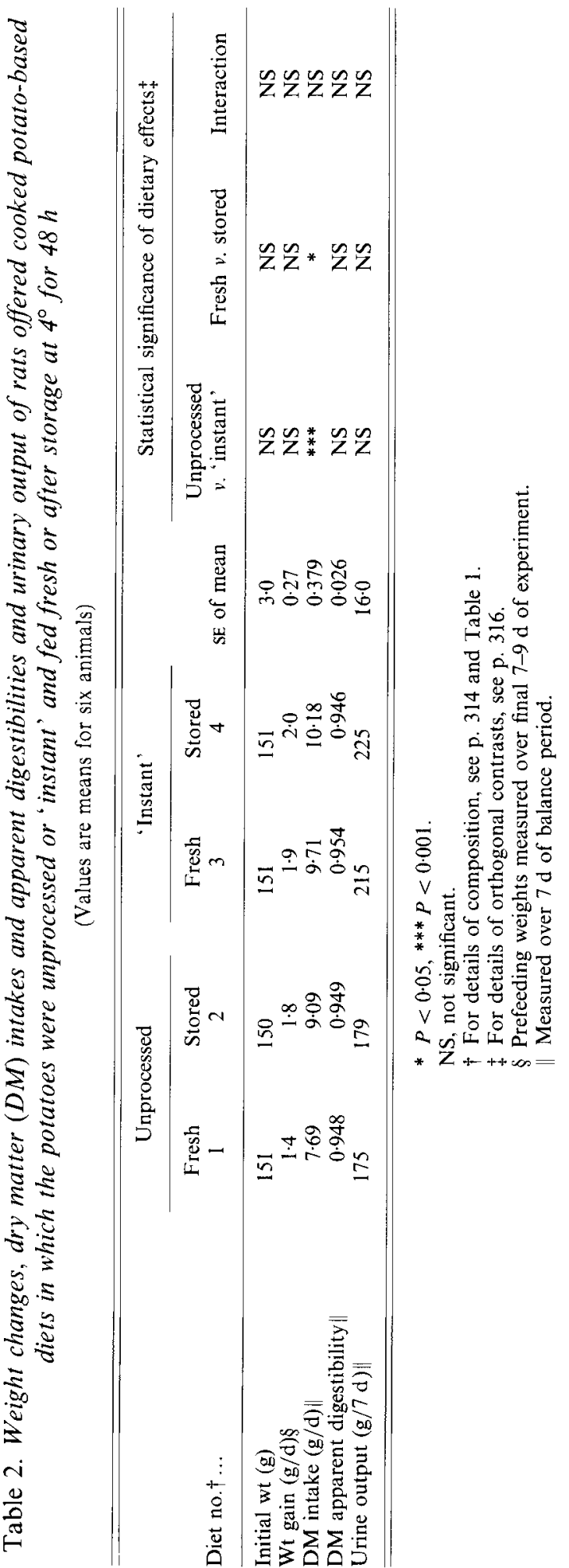


observed for both caecal tissue and contents. For caecal tissue, there was a significant $(P<0.01)$ interaction between processing method and storage, with an increase in tissue mass in rats eating the $48 \mathrm{~h}$ stored 'instant'-potato diet but a decrease in those animals eating the stored unprocessed-potato diet compared with rats eating the equivalent freshlyprepared diets. Liver weights were unaffected by diet with means of $7 \cdot 3,7 \cdot 1,7 \cdot 7$ and $7 \cdot 8$ (SE $0 \cdot 35$ ) $\mathrm{g}$ for diets $1,2,3$, and 4 respectively.

\section{Caecal fermentation}

Storage of the diets at $4^{\circ}$ for $48 \mathrm{~h}$ had no effect on caecal fermentation pattern but feeding 'instant' potatoes significantly reduced caecal $\mathrm{pH}$ and increased caecal total VFA concentration when compared with unprocessed potatoes (Table 4). Caecal VFA pool sizes tended to be lower in animals eating the 'instant'-potato diets, because of the much smaller caecal contents masses (Table 3), but these differences were not statistically significant. There was a significantly higher proportion of butyric acid with lower proportions of propionic and isovaleric acids in caecal VFA from rats fed on 'instant'-potato diets, whilst diet had no significant $(P>0.05)$ effects of molar proportions of acetic, isobutyric and valeric acids.

\section{Coprophagy}

Knowledge of the $\mathrm{Cr}_{2} \mathrm{O}_{3}$ concentrations in food, stomach contents and faeces allowed calculation of the proportions of stomach contents DM derived from food and faeces (assuming that these were the only significant sources of stomach contents DM). At the time of killing, it was calculated that directly ingested food contributed $0.99,0.99,0.99$ and 1.00 (SE 0.005) of stomach contents DM for diets $1,2,3$ and 4 respectively.

\section{Extent and sites of digestion of organic matter}

The higher DM intakes of animals eating the 'instant'-potato diets (Table 2) were reflected in the higher OM intakes reported in Table 5, with a significantly lower intake of the fresh compared with stored diets largely as a result of the relatively low intake for diet 1 . Diet had no significant effect on $O M$ apparent digestibility with an overall mean value of 0.96 associated with a relatively low coefficient of variation of 0.06 . OM flow from the terminal ileum was considerably greater for the 'instant'-potato diets compared with unprocessed, and for the stored compared with freshly-prepared diets. The amount of OM apparently fermented in the LB, calculated as the difference between OM flow from the ileum and OM output in faeces, was very highly significantly $(P<0 \cdot 001)$ greater for animals eating the 'instant'-potato diets than for the others.

Since some of these effects in gastrointestinal OM flow may have been due to the differences between diets in OM intake, the values were also expressed per $\mathrm{kg}$ OM intake. On this basis, OM flow from the terminal ileum into the LB with the 'instant'-potato diets was, on average, 1.4 times that observed with the unprocessed-potato diet and, since OM output in faeces was unaffected by diet, there was a similar increase in the amount of OM apparently fermented in the LB.

\section{$L B$ transit times}

Transit times (TT) of the marker $\mathrm{Cr}_{2} \mathrm{O}_{3}$ in the caecum were approximately twice as long in rats eating unprocessed-potato diets compared with the 'instant'-potato diets, and storage of the diet at $4^{\circ}$ for $48 \mathrm{~h}$ before feeding reduced caecal TT by approximately one-third for each potato type (Table 6). Colonic TT was much shorter than caecal TT but, again, was significantly $(P<0.001)$ longer for the unprocessed-potato-fed animals than for those eating 'instant' potatoes. 


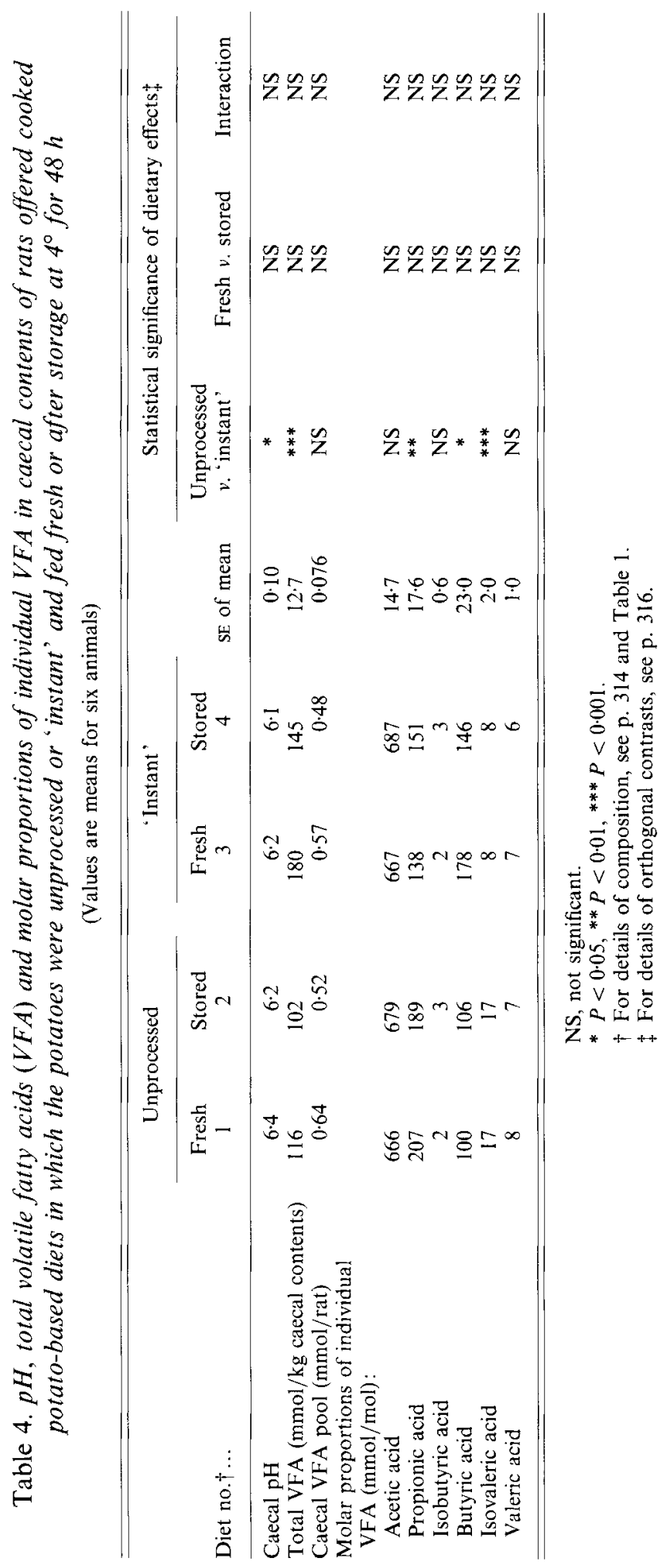


5
5
5
5
5
5
5
5
5
$\vdots$
$\vdots$
5
0
0

$z=$

$\frac{8}{2}+\frac{1}{2}$

$8 \dot{0}$

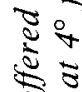

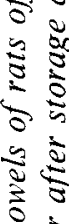

8

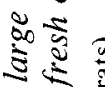

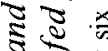

$\approx \stackrel{0}{0}$

蛋.

क

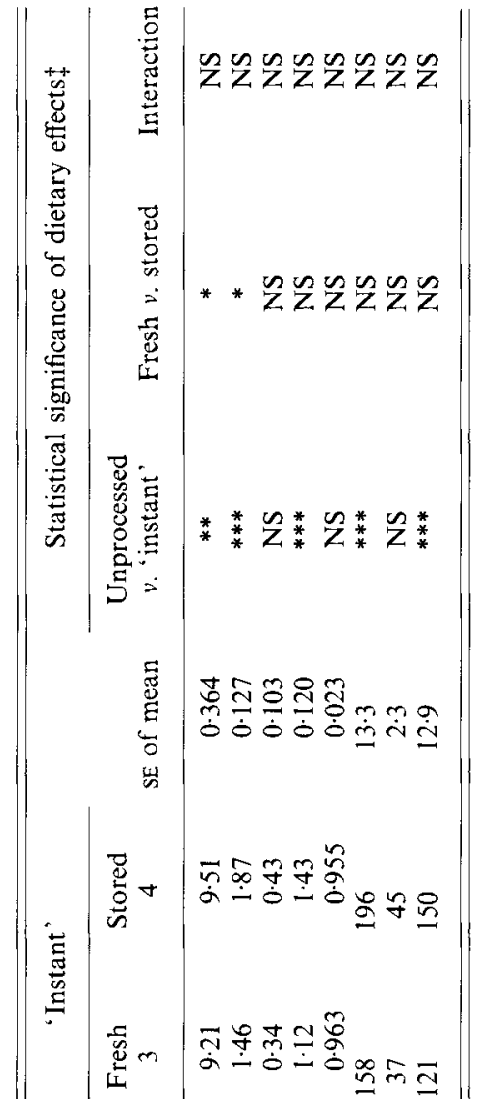

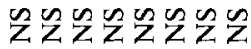

文

文

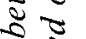

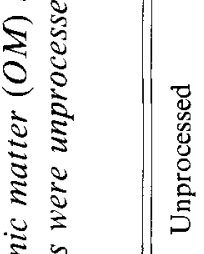

-0்0吕西

迹 它言

ธิ

s

o.

5

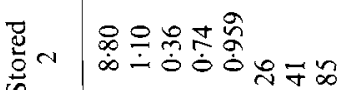

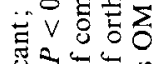

过芯

छे $\overrightarrow{0} \dot{0}$

.

总之施

\% .

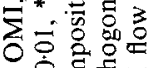

*

⿷匚⿳丨コ丨

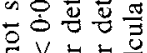

ㄴㅎㅇ

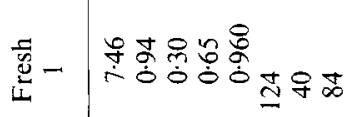

$\tilde{z}^{2}++\infty$ 


\section{Estimated absorption of VFA from the $L B$}

VFA absorbed from the LB were calculated from knowledge of the OM apparently fermented in this organ, i.e. OM disappearance between the terminal ileum and faeces (Table 5) and the molar proportions of the major VFA (acetate, propionate and butyrate) observed in the caecum (Table 4) using conventional anaerobic stoichiometry i.e. that one molecule of hexose can result in two molecules of acetate, two molecules of propionate or one molecule of butyrate (Demeyer \& Van Nevel, 1975), and assuming that these VFA were the only significant organic end-products of fermentation. Given the differences in OM intake (Table 5), values for VFA absorption are reported both in absolute amounts (mmol/d) and also per $\mathrm{kg} \mathrm{OM}$ intake (Table 7). Both methods of expression resulted in similar conclusions about the effects of diet. On a molar basis, acetate was the major acid apparently absorbed with significantly greater amounts being absorbed with the 'instant'potato diets compared with unprocessed-potato diets. There also tended to be more propionate absorbed with the 'instant'-potato diets but between-diets differences were not statistically significant $(P>0 \cdot 05)$. When expressed as mmol per $\mathrm{kg} O \mathrm{OM}$ intake, there was only half as much butyrate as propionate absorbed with the unprocessed-potato diets but similar molar amounts of propionate and butyrate with the 'instant'-potato diets. Total VFA absorption was significantly $(P<0 \cdot 01)$ greater with the 'instant'-potato diets.

\section{DISCUSSION}

\section{Experimental objectives and protocol considerations}

The present experiment was designed to investigate effects on the site and extent of OM digestion and LB fermentation of feeding diets in which 0.8 of the DM was provided by cooked potatoes (the only dietary source of polysaccharides), and which were prepared either by the conventional boiling method or by rehydrating commercially-prepared 'instant' potatoes. Since the variety of potato used in manufacture of the 'instant' potato is not known, it should be borne in mind that differences attributed to potato type (unprocessed $v$. 'instant') may in part be due to inherent differences in the potato varieties. A further objective was to investigate the effects of refrigeration $\left(4^{\circ}\right)$ of the diets for $48 \mathrm{~h}$ before feeding, since the practice of keeping cooked potato cold for some time before eating is widespread in domestic, institutional and commercial catering. Such storage is likely to result in the formation of a starch fraction which is resistant to $\alpha$-amylase (RS; Englyst $\&$ Cummings, $1987 a, b)$.

The experimental objectives resulted in practical difficulties not usually encountered in nutritional experiments with rats. First, potatoes had to be cooked and diets prepared every day, which could have resulted in some between-day variation in composition. This was minimized by adhering strictly to the diet preparation protocol and portions of each day's diet were pooled and analysed to provide a best estimate of diet composition. Second, the diets were high in water content $(0 \cdot 8)$ and of low energy density so that large volumes had to be consumed to meet the rats' nutrient requirements. Since it was important to minimize the formation of RS in the freshly-prepared diets (to provide a contrast with the stored diets), it was necessary to train the rats to consume as much as possible rapidly after the food was offered, and a $4 \mathrm{~h}$ period (10.00-14.00 hours daily) was allowed for this purpose.

Several interesting differences (discussed later) were observed between the 'instant'- and unprocessed-potato diets, but fewer and less marked differences between the freshlyprepared and stored diets. This may have arisen because the $4 \mathrm{~h}$ during which the rats had access to the freshly-prepared diets may have been long enough for retrogradation of some starch to form RS, as would also have occurred in the cold-stored diets, so reducing potential differences between the diets. After the present study had been completed, further portions of the 'instant'-potato diet (using the same batch of rat materials) and of the fresh- 


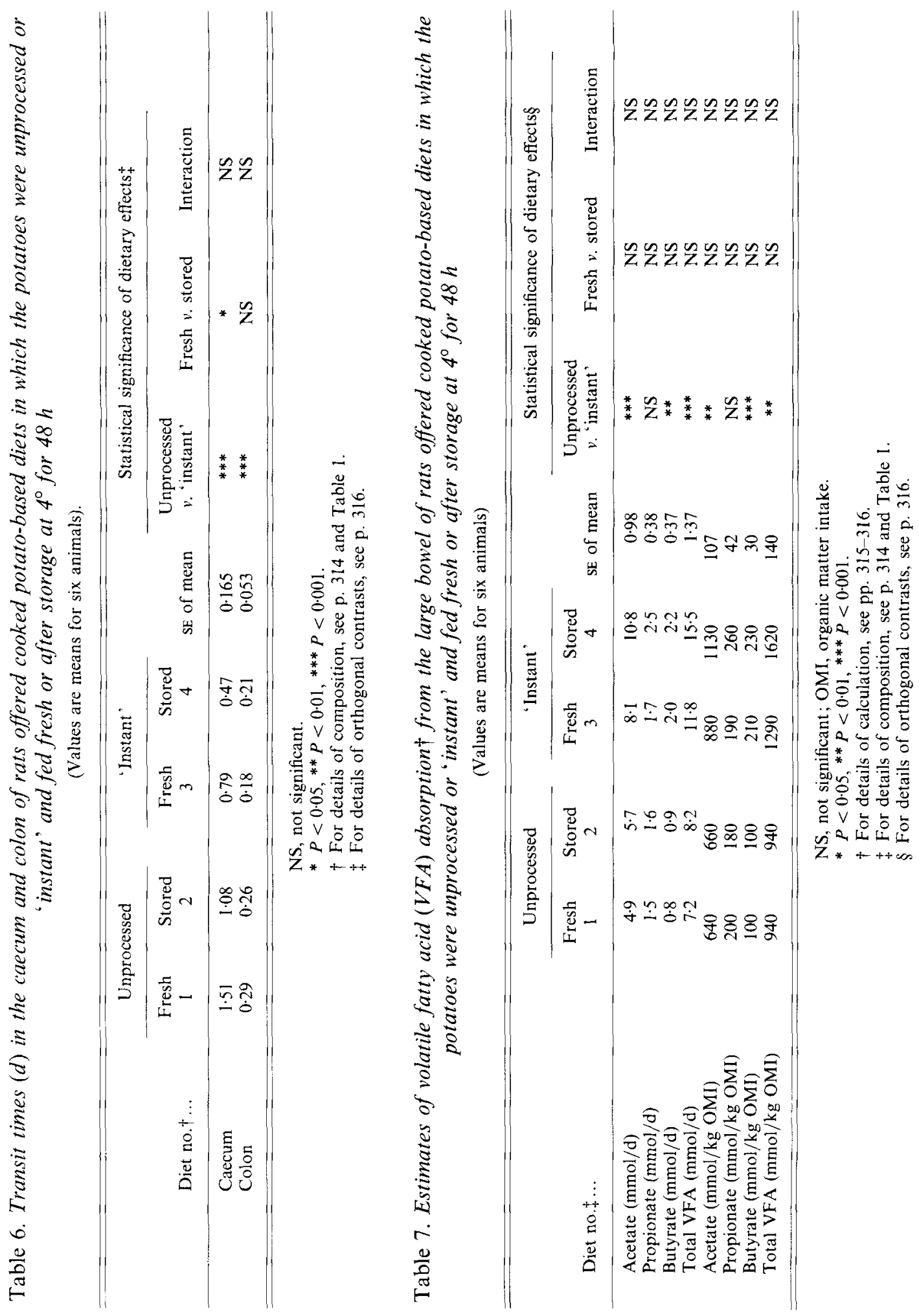




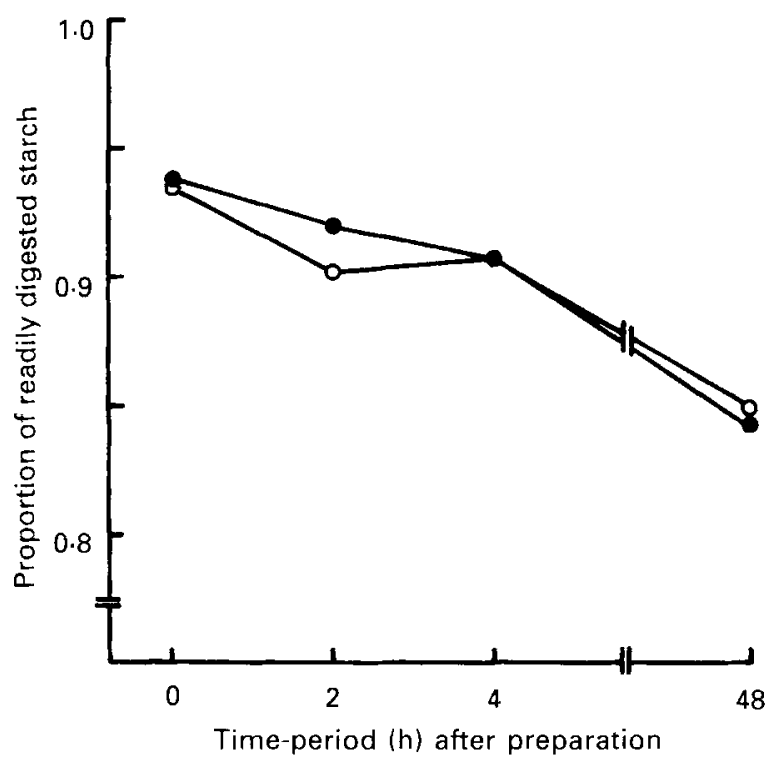

Fig. 1. Readily digested starch as a proportion of total starch in samples of unprocessed-potato (var. Pentland Squire) (-) and 'instant'-potato $(\mathrm{O}-\mathrm{O})$ diets at $0,2,4$ and $48 \mathrm{~h}$ after preparation. Points are means of two determinations. For details of diets and procedures, see pp. 314-316.

potato diet (using the var. Pentland Squire) were prepared and assayed for total and readily digested starch immediately, and at 2,4 and $48 \mathrm{~h}$ after preparation. The $48 \mathrm{~h}$ sample was stored at $4^{\circ}$ as in the main experiment. As expected, the proportion of starch which was readily digested by pancreatin fell with time after preparation with very similar values for both the unprocessed and 'instant'-potato diets (Fig. 1).

\section{Sites and extent of digestion}

Overall mouth-to-faeces digestibility of both DM and OM were high, as expected, and did not differ between diets. With all diets, a considerable proportion $(0 \cdot 12-0 \cdot 20)$ of the ingested OM flowed from the terminal ileum but most of this $(0.67-0.77)$ disappeared within the LB, presumably as a result of fermentation. The flow of fermentable material into the LB of normal healthy human subjects given microwave-cooked potato has been assessed by the $\mathrm{H}_{2}$ excretion method and found to correspond to approximately $0 \cdot 08-0 \cdot 10$ of ingested carbohydrate (Levitt et al. 1987), in good agreement with our observations given in Table 5. The composition of this OM escaping digestion in the small bowel has not been examined in detail, but preliminary investigations suggest that starch may account for only $0 \cdot 15-0 \cdot 21$ of the OM flowing into the LB (J. C. Mathers \& L. D. Dawson, unpublished results) which would correspond to approximately $0.04-0.06$ of the ingested starch. For comparison, direct measurement of the starch flowing from ileum of healthy ileostomates indicated that 0.03 (freshly-cooked potato) to 0.12 (cooked and cooled potato) of the ingested potato starch escaped small intestinal digestion (Englyst \& Cummings, 1987a). When mixed diets containing wheat and potato starch were eaten, 0.01-0.05 of ingested starch was recovered in the ileal effluent of healthy ileostomates (Chapman et al. 1985).

A greater proportion of the ingested $O M$ flowed from the terminal ileum with the 'instant'-potato diets which suggests that the rehydrated 'instant'-potato contained components which were more resistant to small intestinal digestion or, alternatively, that these diets promoted the flow of additional endogenous $O M$ to the terminal ileum. 
Carbohydrate digestion, within the human small intestine, of freshly-prepared instant potato from a different manufacturer (Cadburys Smash ${ }^{\mathbb{B}}$ ) was similar to that of freshlycooked potato in a study by Englyst \& Cummings (1987a). There was no evidence that 'instant' potato undergoes retrogradation more rapidly or extensively than the conventionally-prepared product in the present study (Fig. 1).

\section{LB fermentation and caecal hypertrophy}

Despite similar diet compositions, markedly different patterns of caecal fermentation were established with higher $\mathrm{pH}$, lower total concentrations of VFA and longer TT in rats eating the unprocessed potatoes. The larger caecal size, smaller amount of OM fermented daily and much longer TT in the latter rats meant that these animals experienced a much reduced fermentation rate (amount of OM fermented per unit mass of caecal contents per unit time). If caecal steady-state is assumed, then it can be calculated that the caecal VFA pool was turned over 2.4 times as rapidly for diet 4 ('instant'-potato diet fed after storage) as for diet 1 (unprocessed-potato diet fed fresh). There is no obvious reason for these effects on caecal fermentation pattern and other studies in which additional fermentable material was provided have given divergent results. Inclusion of raw peas (Pisum sativum) in an otherwise non-starch polysaccharide (NSP)-free diet also reduced caecal TT and, at low pea inclusion levels, caecal mass; but caecal mass increased as greater amounts of peas and, therefore, fermentable material, were eaten (Goodlad \& Mathers, 1990). Inclusion of black eye beans (Vigna unguiculata) in a white-rice diet let to a doubling of caecal weight but was without effect on caecal TT (Mathers et al. 1990). However, all three of these studies were consistent in showing increases in the molar proportion of butyrate in the caecal VFA with diets which supplied greater amounts of fermentable material to the LB. Possible reasons for this shift in fermentation pattern are discussed by Goodlad \& Mathers (1990) with particular attention being given to the observations of high butyrate fermentations with starch as substrate in vitro (Englyst et al. 1987; Goodlad \& Mathers, 1988), in rats fed on amylomaize (a source of starch relatively resistant to pancreatic amylase; Mallett et al. 1988) and in human subjects consuming high-starch diets and taking the $\alpha$-glucosidase (EC 3.2.1.20) inhibitor acarbose (Scheppach et al. 1988b). However, substrate supply may not be the only factor influencing fermentation end-product pattern. Other environmental effects may also exert selective pressure on the LB microbes altering the balance between species (Mathers et al. 1990) or between metabolic pathways. In general, higher proportions of butyrate accompany shorter caecal TT (Fig. 2). The values in Fig. 2 suggest that caecal butyrate proportion is particularly sensitive to changes in caecal TT below about $0.75 \mathrm{~d}$ and the effects of caecal butyrate proportion of altering TT over the range $0 \cdot 3-0.75 \mathrm{~d}$ deserves further study. Under these circumstances greater butyrate synthesis may be a means for disposing of reducing equivalents to enable glycolysis to proceed rapidly (Leng, 1970; Goodlad \& Mathers, 1990).

Rats fed on the unprocessed potatoes had larger caecums with both more tissue and more contents than those eating 'instant' potatoes. It has frequently been reported (for example, see Wyatt et al. 1988; Rémésy \& Demigné, 1989; Seal \& Mathers, 1989) that increased intake of carbohydrates which are not digested in the small intestine results in enlarged caecums. When these carbohydrates are fermented in the LB, VFA are produced and it has been shown that direct infusion of VFA into the distal intestine stimulates gut epithelial proliferation with butyrate provoking more rapid proliferation than propionate or acetate (Sakata, 1987). This led to the suggestion that the VFA, and in particular butyrate, are lumen trophic factors (Sakata, 1987). However, caecal hypertrophy also occurs when non-digestible polysaccharides which are not (or only poorly) fermented are fed (Wyatt et al. 1988) and in the germ-free animal (Goodlad et al. 1989) in the absence of 


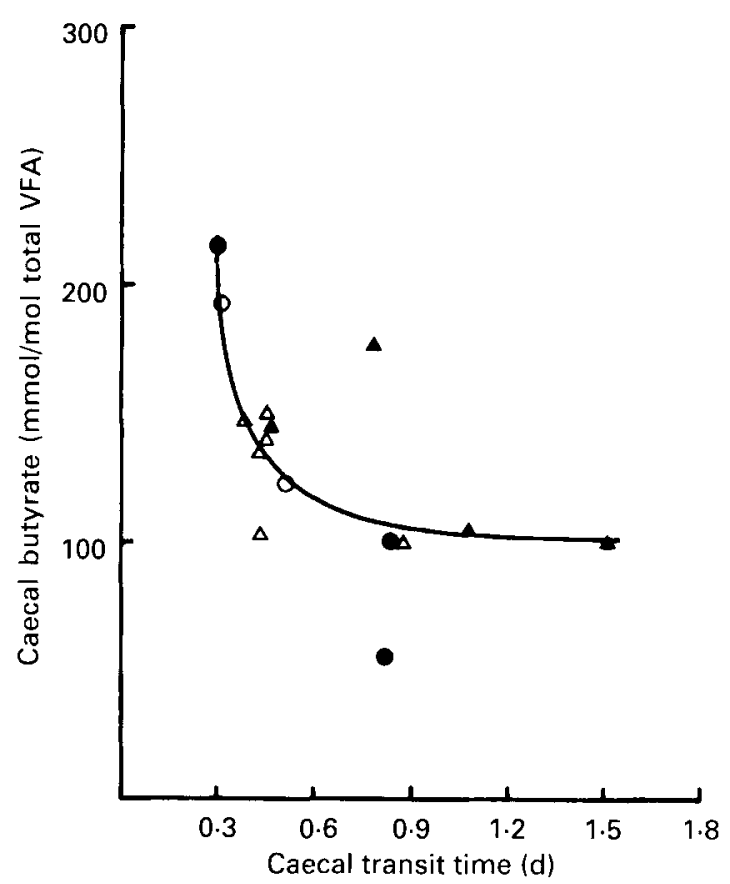

Fig. 2. Relationship between molar proportion of butyrate in volatile fatty acids (VFA) in caecal contents ( $y$ ) and caecal transit time $(x)$ in rats fed on various diets. Values are taken from (O) Mathers \& Fotso Tagny (1989) (using means for each diet), (O) Mathers et al. (1990), ( $\triangle$ ) Goodlad \& Mathers (1990) and ( $\Delta$ ) the present study. The fitted line is an hyperbola of the form: $y=94 \cdot 3-\{36 \cdot 7 /(1-4 \cdot 35 x)\}$, which accounted for 0.60 of the variation in $y$.

fermentation. An alternative hypothesis has been proposed by Wyatt et al. (1988) who suggested that LB hypertrophy is 'not primarily a response to bacterial fermentation' but that 'the caecum enlarges to accommodate the tendency of residual material to accumulate within it, and this is governed by the pattern of motility and bulk flow through the whole large bowel'. Our experiment provides no support for Sakata's (1987) hypothesis since more total VFA and more butyrate were produced with the 'instant'-potato diets yet these had smaller caecums. In addition, in our study there was more caecal tissue with the unprocessed-potato diets where there was more 'residual material' (wet caecal contents) in agreement with the observations of Wyatt et al. (1988), but it is not at all clear why this greater accumulation of caecal contents should have occurred since there was less material flowing into the LB from the ileum with these diets. Further study of the relationships between substrate flow, the activities of caecal flora and LB motility may be helpful in understanding in which circumstances 'residual material' accumulates in the caecum and how this influences tissue hypertrophy.

\section{Coprophagy}

Coprophagy is practised by many animals, especially rodents such as the rat (Hörnicke \& Björnhag, 1980), with very variable amounts of faeces apparently being ingested under different circumstances. Measurement of the quantity of faeces ingested has often been made by indirect methods involving comparison of faecal output from animals fitted with tail cups (which prevent re-ingestion) with that from animals allowed to practise coprophagy (Fajardo \& Hörnicke, 1989). Such studies have indicated that with 
nutritionally-complete diets there is relatively little re-ingestion $(0-11 \%)$ but this can rise to $25 \%$ (Fajardo \& Hörnicke, 1989) or more (Hörnicke \& Björnhag, 1980) with unbalanced or nutrient-deficient diets. Such re-ingestion of faeces could affect the interpretation of gastrointestinal flow and TT studies where an indigestible marker (such as $\mathrm{Cr}_{2} \mathrm{O}_{3}$ in the present study) is used. It was important, therefore, to ascertain the extent of coprophagy by our animals and we did this by a simple and apparently novel method, i.e. comparison of the concentration of marker in stomach contents DM with that in food and in faeces. This calculation assumes that food and faeces are the only significant contributors to stomach contents DM. In our study there was no evidence of significant re-ingestion of faeces and so classical marker-ratio methods may be used with confidence, but this may not always be the case and appropriate checks should be made.

\section{Possible implications for tissue metabolism and health}

The increased flow of OM to the LB and reduced TT in both the caecum and colon with the 'instant'-potato diets would, if they occurred in man, be beneficial in alleviating constipation. These 'instant'-potato diets were also responsible for the apparent absorption of larger amounts of VFA provided by both acetate and butyrate. Increased butyrate production may be beneficial since it is a preferred energy substrate for the LB mucosa (Roediger, 1980, 1982) and is reported to have anti-neoplastic properties (Cummings \& Branch, 1982) but could be contra-indicated in those with compromized livers. The longerchain VFA, propionate and butyrate, are found in human peripheral blood only in exceptional circumstances usually associated with liver damage (Trauner et al. 1975; Lai et al. 1977), and the hepatic removal of longer-chain VFA in the healthy individual may be protective since butyrate by-passing the liver into the systemic circulation has narcotic effects (Samson et al. 1956; Walker et al. 1970) and may be a factor in the aetiology of hepatic encephalopathy (Zieve \& Nicoloff, 1975). Increased absorption of acetate is unlikely to have any detrimental effect on tissue metabolism since it is a normal blood metabolite which can be oxidized or used for synthetic purposes by many tissues. Recent studies have shown that additional gut-derived acetate has no significant effect on glucose metabolism in man (Scheppach et al. $1988 a, c$ ).

The authors thank Julia Kennard for assistance with the starch determinations.

\section{REFERENCES}

Anderson, I. H., Levine, A. S. \& Levitt, M. D. (1981). Incomplete absorption of the carbohydrate in all-purpose wheat flour. New England Journal of Medicine 304, 891-892.

Chapman, R. W., Sillery, J. K., Graham, M. M. \& Saunders, D. R. (1985). Absorption of starch by healthy ileostomates: effect of transit time and of carbohydrate load. American Journal of Clinical Nutrition 41, $1244-1248$

Cummings, J. H. \& Branch, W. J. (1982). Postulated mechanisms whereby fiber may protect against large bowel cancer. In Dietary Fiber in Health and Disease, pp. 313-325 [G. V. Vahouny and D. Kritchevsky, editors]. London: Plenum Press.

Demeyer, D. I. \& Van Nevel, C. J. (1975). Methanogenesis, an integrated part of carbohydrate fermentation, and its control. In Digestion and Metabolism in the Ruminant, pp. 366-382 [I. W. McDonald and A. C. I. Warner, editors]. Armidale: University of New England Publishing Unit.

Demigné, C. \& Rémésy, C. (1982). Influence of unrefined potato starch on cecal fermentations and volatile fatty acid absorption in rats. Journal of Nutrition 112, 2227-2234.

Englyst, H. N. \& Cummings, J. H. (1985). Digestion of the polysaccharides of some cereal foods in the human small intestine. American Journal of Clinical Nutrition 42, 778-787.

Englyst, H. N. \& Cummings, J. H. (1986). Digestion of the carbohydrates of banana (Musa paradisiaca sapientum) in the human small intestine. American Journal of Clinical Nutrition 44, 42-50.

Englyst, H. N. \& Cummings, J. H. (1987a). Digestion of the polysaccharides of potato in the small intestine of man. American Journal of Clinical Nutrition 45, 423-431. 
Englyst, H. N. \& Cummings, J. H. (1987 b). Resistant starch, a 'new' food component : a classification of starch for nutritional purposes. In Cereals in a European Context, pp. 221-233 [I. D. Morton, editor]. Chichester: Ellis Horwood Ltd.

Englyst, H. N., Hay, S. \& Macfarlane, G. T. (1987). Polysaccharide breakdown by mixed populations of human faecal bacteria. FEMS Microbiological Letters 45, 163-171.

Faichney, G. J. (1975). The use of markers to partition digestion within the gastro-intestinal tract of ruminants. In Digestion and Metabolism in the Ruminant, pp. 277-291 [I. W. McDonald and A. C. I. Warner, editors]. Armidale: University of New England Publishing Unit.

Fajardo, G. \& Hörnicke, H. (1989). Problems in estimating the extent of coprophagy in the rat. British Journal of Nutrition 62,551-561.

Flourié, B., Leblond, A., Florent, Ch, Rautureau, M., Bisalli, A. \& Rambaud, J.-C. (1988). Starch malabsorption and breath gas excretion in healthy humans consuming low- and high-starch diets. Gastroenterology $\mathbf{9 5}$, $356-363$.

Goodlad, J. S. \& Mathers, J. C. (1987). Digesta flow from the ileum and transit time through the caecum of rats given diets containing graded levels of peas. Proceedings of the Nutrition Society 46, 149A.

Goodlad, J. S. \& Mathers, J. C. (1988). Effects of food carbohydrates on large intestinal fermentation in vitro. Proceedings of the Nutrition Society 47, 176A.

Goodlad, J. S. \& Mathers, J. C. (1990). Large bowel fermentation in rats given diets containing raw peas (Pisum sativum). British Journal of Nutrition 64, 569-587.

Goodlad, R. A., Ratcliffe, B., Fordham, J. P. \& Wright, N. A. (1989). Does dietary fibre stimulate intestinal epithelial cell proliferation in germ free rats? Gut 30, 820-825.

Hörnicke, H. \& Björnhag, G. (1980). Coprophagy and related strategies for digesta utilization. In Digestive Physiology and Metabolism in Ruminants, pp. 707-730 [Y. Ruckebusch and P. Thivend, editors]. Lancaster: MTP Press Ltd.

Lai, J. C. K., Silk, D. B. A. \& Williams, R. (1977). Plasma short-chain fatty acids in fulminant hepatic failure. Clinica Chimica Acta 78, 305-310.

Leng, R. A. (1970). Formation and production of volatile fatty acids in the rumen. In Physiology of Digestion and Metabolism in the Ruminant, pp, 406-421 [A. T. Philipson, editor]. Newcastle upon Tyne: Oriel Press.

Levitt, M. D., Hirsch, P., Fetzer, C. A., Sheahan, M. \& Levine, A. S. (1987). $\mathrm{H}_{2}$ excretion after ingestion of complex carbohydrates. Gastroenterology 92, 383-389.

Mallett, A. K., Bearne, C A., Young, P. J., Rowland, I. R. \& Berry, C. (1988). Influence of starches of low digestibility on the rat caecal microflora. British Journal of Nutrition 60, 597-604.

Mathers, J. C., Fernandez, F., Hill, M. J., McCarthy, P. T., Shearer, M. J. \& Oxley, A. (1990). Dietary modification of potential vitamin $\mathrm{K}$ supply from enteric bacterial menaquinones in rats. British Journal of Nutrition 63, 639-652.

Mathers, J. C. \& Fotso Tagny, J.-M. (1989). Diurnal variation in large bowel metabolism in rats given diets with and without wheat bran. Proceedings of the Nutrition Society 48, 52A.

Rémésy, C. \& Demigné, C. (1989). Specific effects of fermentable carbohydrates on blood urea flux and ammonia absorption in the rat cecum. Joumal of Nutrition $119,560-565$.

Roediger, W. E. W. (1980). Role of anaerobic bacteria in the metabolic welfare of the colonic mucosa of man. Gut 21, 793-798.

Roediger, W. E. W. (1982). Utilization of nutrients by isolated epithelial cells of the rat colon. Gastroenterology 83, $424-429$.

Ross, G. J. S. (1980). Maximum Likelihood Program. Harpenden: Rothamsted Experimental Station.

Sakata, T. (1987). Stimulatory effect of short-chain fatty acids on epithelial cell proliferation in the rat intestine: a possible explanation for trophic effects of fermentable fibre, gut microbes and luminal trophic factors. British Journal of Nutrition 58, 95-103.

Samson, F. E., Dahl, N. \& Dahl, D. R. (1956). A study on the narcotic actions of the short chain fatty acids. Journal of Clinical Investigation 35, 1291-1298.

Scheppach, W., Cummings, J. H., Branch, W. J. \& Schrezenmeir, J. (1988a). Effect of gut-derived acetate on oral glucose tolerance in man. Clinical Science 75, 355-361.

Scheppach, W., Fabian, C., Sachs, M. \& Kasper, H. (1988b). The effect of starch malabsorption on fecal shortchain fatty acid excretion in man. Scandinavian Journal of Gastroenterology 23, 755-759.

Scheppach, W., Wiggins, H. S., Halliday, D., Self, R., Howard, J., Branch, W. J., Schrezenmeir, J. \& Cummings, J. H. (1988c). Effect of gut-derived acetate on glucose turnover in man. Clinical Science 75, 363-370.

Seal, C. J. \& Mathers, J. C. (1989). Intestinal zinc transfer by everted gut sacs from rats given diets containing different amounts and types of dietary fibre. British Journal of Nutrition 62, I51-163.

Stephen, A. M., Haddad, A. C. \& Phillips, S. F. (1983). Passage of carbohydrate into the colon. Direct measurements in humans. Gastroenterology 85, 589-595.

Thompson, A. (1970). Rat metabolism cage. Journal of the Institute of Animal Technicians 21, 12-21.

Trauner, D. A., Nyhan, W. L. \& Sweetman, L. (1975). Short-chain organic acidemia and Reye's syndrome. Neurology 25, 296-298.

Walker, C. O., McCandless, D. W., McGarry, J. D. \& Schenker, S. (1970). Cerebral energy metabolism in shortchain fatty acid-induced coma. Journal of Laboratory and Clinical Medicine 76, 569-583. 
Woolfe, J. A. (1987). The Potato in the Human Diet. Cambridge: Cambridge University Press in collaboration with the International Potato Centre.

Wyatt, G. M., Horn, N., Gee, J. M. \& Johnson, I. T. (1988). Intestinal microflora and gastrointestinal adaptation in the rat in response to non-digestible dietary polysaccharides. British Journal of Nutrition 60, 197-207.

Zieve, L. \& Nicoloff, D. M. (1975). Pathogenesis of hepatic coma. Annual Review of Medicine 26, 143-157. 